\title{
Analysis of the Impact of Leadership Determination on Employee Performance at PT BTN (Persero), Tbk Medan Sharia Branch Office
}

\author{
Novriadi $\mathbf{M}^{1}$, Harmein Nasution ${ }^{2}$, Yeni Absah ${ }^{2}$ \\ ${ }^{1,2}$ Master of Management Study Program on Postgraduate School of University of Sumatera Utara
}

Corresponding Author: Novriadi M

\begin{abstract}
Not achieving the Key Performance Index (KPI) target within 5 consecutive years can be used as an indicator of the lack of maximum management in the company in facing competition. In-depth considerations are needed to answer the problems that occur related to this performance decline. Referring to several studies conducted related to motivation and performance, it is known that many variables can affect performance. The purpose of this study was to determine and analyze the influence of transformational, democratic and situational leadership styles on employee performance at PT Bank Tabungan Negara (Persero), Tbk Sharia Medan Branch Office. The population in this study were all employees who worked at PT Bank Tabungan Negara (Persero), Tbk Sharia Medan Branch Office. Many samples in this study were as many as $\mathbf{5 0}$ respondents. Data were collected using observations and questionnaires. The data is tested using validity and reliability tests, and the data must meet the elements of the classical assumption test. Furthermore, the data analysis test was carried out using multiple regression analysis; $t$ test, $F$ test, and the coefficient of determination. The results of this study indicate that there is a significant influence on the transformational, democratic and situational leadership style either partially or simultaneously. The amount of Transformational Leadership, Democratic Leadership and Situational Leadership explains that employee performance is 0.689 or equal to $68.90 \%$ while the remaining $31.10 \%$ is explained by other variables.
\end{abstract}

Keywords: Transformational, Democratic, Situational, Performance Leadership

\section{BACKGROUND}

The banking business is currently one of the most competitive businesses. It is not easy to survive in the banking business today. The current growth of the banking business creates a very tight competition and it is not easy to survive in this business considering the many banks and other financial institutions that have been established. Therefore, to be able to survive in this business, the company must have good performance for every employee it has. Performance is defined as the quality and quantity of work achieved by an employee in carrying out his duties in accordance with the responsibilities given to him (Mangkunegara, 2012).

The data shows that the performance of the employees of PT Bank Tabungan Negara (Persero), Tbk Medan Syariah Branch Office is less than the maximum as indicated by the value of the Key Performance Indicator (KPI). KPI is a tool that can be used to measure the level of performance of company employees on what has been done to maximize company profits.

Failure to achieve KPI targets within 5 consecutive years can be used as an indicator of the company's management being less than optimal in facing competition. This is certainly not good for the management of the company as a whole. 
Therefore, PT Bank Tabungan Negara (Persero), Tbk Medan Syariah Branch Office is required to optimize the performance of its employees in providing services to the community.

Table 1: Key Performance Indicator PT BTN (Persero), Tbk Sharia Medan Branch Office Period 2015 - 2019

\begin{tabular}{|c|c|c|c|c|}
\hline \multirow{2}{*}{ Year } & \multicolumn{3}{|c|}{ Comparison of Targets and Actual KPI's } & \multirow{2}{*}{ Conclusion } \\
\cline { 2 - 4 } & Target (\%) & Realization $(\boldsymbol{\%})$ & Difference+/- & \\
\hline 2015 & 100,00 & 80,08 & $-19,92$ & Not achieved \\
\hline 2016 & 100,00 & 83,53 & $-16,47 \%$ & Not achieved \\
\hline 2017 & 100,00 & 76,95 & $-23,05$ & Not achieved \\
\hline 2018 & 100,00 & 70,99 & -29.01 & Not achieved \\
\hline 2019 & 100,00 & 69,04 & $-30,96$ & Not achieved \\
\hline
\end{tabular}

Referring to several studies conducted related to motivation and performance, it is known that there are many variables that can affect performance. Several studies have been conducted to look at factors or variables that can affect the increase or decrease in the performance of an employee or company, including those conducted by Feby, et al (2019); Indar, et al (2019); Sunaryo (2018); Mokhamad (2017) which shows the results that leadership style is one of the important factors for companies to improve employee and company performance. The results of observations and interviews with several employees can be seen the employee's perception of the current leadership. Each employee gives a different perception, some like the current leadership of the company's management, some don't like it. This difference in perception between employees makes the work motivation of each employee also different, which ultimately makes the individual performance of employees also different but tends to be less than optimal. If so, it will have an impact on the company's overall performance. Furthermore, it is necessary to know other leadership styles that are thought to cause a decrease in performance. Research conducted by (Anshar, 2019) uses a democratic leadership style to measure the performance of the apparatus. This democratic leadership can be interpreted as a leader who is fully responsible and views his group as an inseparable part of himself so that the expected goals can be achieved optimally (Baharuddin\&Umiarso, 2012).

\section{Transformational Leadership}

According to Yukl (2013), transformational leadership is a condition in which followers of a transformational leader feel trust, admiration, loyalty, and respect for the leader, and they are motivated to do more than they initially expected. The leader transforms and motivates followers by making them more aware of the importance of the results of a job, encouraging them to put the organization or team above their own interests, and activating their needs at a higher level.

\section{Democratic Leadership}

According to Rivai (2014) democratic leadership styles generally assume that the opinion of the crowd is better than their own opinion and participation will lead to responsibility for its implementation. Another assumption is that participation provides opportunities for members to develop themselves. In carrying out his duties, a democratic leader is willing to accept and even expect opinions and input from all members of the organization. However, in every decision making, the leader must be able to refer to the goals of the organization by optimizing all the potential resources available. Democratic leaders are always populist with all members of the organization. His relationship with the members is not like the relationship between an employer and his subordinates, but as a leader who always behaves in a familial manner, which can be a brother to his brothers and sisters. 


\section{Situational Leadership}

The word leader has various meanings. There are many definitions of the leader, namely as many individuals who are interested in the problem of the leader. Therefore, leadership style is an interactive impact of individual/personal factors with situational factors. This situational leadership theory was first introduced by Hersey and Blonchard (1982) which states that situational leadership is the ability and willingness of people to be responsible for directing their own behavior, related to specific tasks that must be done.

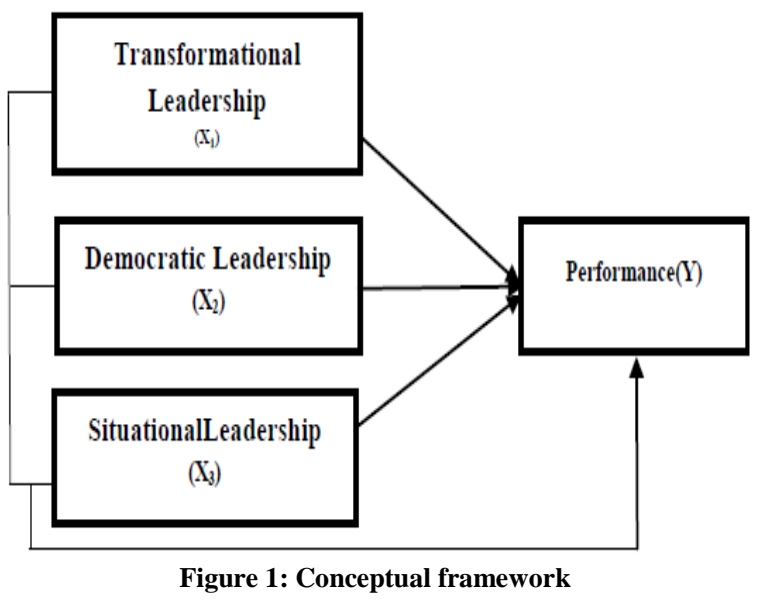

\section{Hypothesis}

1. Transformational Leadership has a positive and significant effect on Employee Performance at PT Bank Tabungan Negara (Persero), Tbk Medan Syariah Branch Office.

2. Democratic Leadership has a positive and significant effect on employee performance at PT Bank Tabungan
Negara (Persero), Tbk Medan Sharia Branch Office

3. Situational Leadership has a positive and significant effect on employee performance at PT Bank Tabungan Negara (Persero), Tbk Medan Syariah Branch Office.

4. Transformational Leadership, Democratic Leadership and Situational Leadership have a positive and significant impact on employee performance at PT Bank Tabungan Negara (Persero), Tbk Medan Syariah Branch Office

\section{RESEARCH METHODS}

The type of research used in this research is descriptive quantitative. The populations in this study were all 50 employees of PT Bank Tabungan Negara (Persero) Tbk Medan Syariah Branch Office. The sampling technique used in this study is a non-probability technique with a saturated method, namely the sample selection method in which each member of the population is a member of the sample. Thus, the sample size of this study was 50 people. In this study, data collection was carried out by distributing questionnaires to respondents.

\section{RESULT AND DISCUSSION Coefficient of Determination}

This determination test is to see how much transformational leadership style, democratic leadership style and situational leadership style can explain performance.

Table 2

Coefficient of Determination

\begin{tabular}{|c|c|c|c|c|}
\hline \multicolumn{5}{|c|}{ Model Summary $^{\mathrm{b}}$} \\
\hline Model & $\mathbf{R}$ & R Square & Adjusted R Square & Std. Error of the Estimate \\
\hline 1 & $.841^{\mathrm{a}}$ & .708 & .689 & 2.87521 \\
\hline \multicolumn{5}{|c|}{ a. Predictors: (Constant), Situational, Transformational, Democratic } \\
\hline \multicolumn{5}{|c|}{ b. Dependent Variable: Performance } \\
\hline
\end{tabular}

Transformational leadership style, democratic leadership style and situational leadership style are able to explain the performance in the amount of $68.90 \%$, the remaining $31.10 \%$ is explained by other variables that are not included in this research model. 


\section{Simultaneous Testing (F Test)}

\begin{tabular}{|c|c|c|c|c|c|c|}
\hline \multicolumn{7}{|c|}{$\begin{array}{c}\text { Table3 } \\
\text { Simultaneous Hypothesis Testing }\end{array}$} \\
\hline & \multicolumn{6}{|c|}{ ANOVA $^{\mathrm{a}}$} \\
\hline & Model & Sum of Squares & df & Mean Square & $\mathbf{F}$ & Sig. \\
\hline \multirow[t]{3}{*}{ 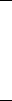 } & Regression & 922.145 & 3 & 307.382 & 37.182 & $.000^{\mathrm{b}}$ \\
\hline & Residual & 380.275 & 46 & 8.267 & & \\
\hline & Total & 1302.420 & 49 & & & \\
\hline & & a. Dependent V & iabl & Performance & & \\
\hline
\end{tabular}

the value of $\mathrm{F}_{\text {count }}$ is 37,182 which is greater than $\mathrm{F}_{\text {table }}$ of $2.81(37.182>2.81)$ with the probability value in this test is 0.000 . The probability value is smaller than the alpha value (0.05) so it can be concluded that the transformational leadership style, democratic leadership style and situational leadership style simultaneously have a significant effect on performance.

\section{Partial Test (t Test)}

Table 4

Partial Hypothesis Testing Coefficients $^{\text {a }}$

\begin{tabular}{|c|c|c|c|c|c|c|c|c|}
\hline \multicolumn{9}{|c|}{ Coefficients $^{\mathrm{a}}$} \\
\hline \multirow{2}{*}{\multicolumn{2}{|c|}{ Model }} & \multicolumn{2}{|c|}{ Unstandardized Coefficients } & \multirow{2}{*}{$\begin{array}{c}\text { Standardized Coefficients } \\
\text { Beta }\end{array}$} & \multirow[t]{2}{*}{$\mathbf{t}$} & \multirow[t]{2}{*}{ Sig. } & \multicolumn{2}{|c|}{ Collinearity Statistics } \\
\hline & & B & Std. Error & & & & Tolerance & VIF \\
\hline \multirow[t]{4}{*}{1} & (Constant) & 8.072 & 4.473 & & 1.805 & .078 & & \\
\hline & Transformational & .890 & .103 & .723 & 8.600 & .000 & .897 & 1.114 \\
\hline & Democratic & .216 & .095 & .193 & 2.281 & .027 & .891 & 1.122 \\
\hline & Situational & .185 & .084 & .194 & 2.191 & .034 & .808 & 1.237 \\
\hline
\end{tabular}

It is known that the transformational leadership style variable has a tcount value of 8.600, when compared with the ttable value, the resulting $8.600>2.013$ with a significance level of 0.000 is smaller than the research alpha value of 0.05 , thus it can be concluded that the transformational leadership style has a significant effect on performance.

The democratic leadership style variable has a tcount value of 2.281 , when compared with the ttable value, the resulting $2.281>2.013$ with a significance level of 0.027 is smaller than the research alpha value of 0.05 , thus it can be concluded that the democratic leadership style has a significant effect on employee performance.

The situational leadership style variable has a tcount value of 2.191 , when compared with the ttable value, the resulting $2.191>2.013$ with a significance level of 0.034 is smaller than the research alpha value of 0.05 , thus it can be concluded that situational leadership style has a significant effect on performance.
Transformational Leadership Style at PT. Bank Tabungan Negara (Persero), Tbk Medan Sharia Branch Impact on Employee Performance

The transformational style of the leadership at PT Bank Tabungan Negara (Persero), Tbk Medan Syariah Branch is also reflected in the freedom given by the leadership to employees to work as optimally as possible, the manifestation of this freedom is to give employees the breadth to be creative in their work with guaranteed results achieved, according to the desired target. In addition to the things already mentioned, the company's leadership provides motivation to all employees. Every day the head of the company holds a meeting with all his subordinates to provide motivation, attention and evaluate what has been done by his subordinates and give advice to his subordinates what should be done to complete the work that is still pending due to problems.

Leaders have tried to set a good example to their subordinates as a form of responsibility to the company to improve 
employee performance. The leader tries to make what he does motivates and inspires his subordinates to work as well as possible to achieve the targeted performance. Indirectly, the transformational leadership styles carried out by the leader makes subordinates have an open mind to be better and have high performance. Transformational leadership style is one of the variables that have a high influence. It is known statistically that the magnitude of the influence of transformational leadership style on performance is 0.890 which is the highest influence compared to other variables.

\section{Democratic Leadership Style at PT. Bank Tabungan Negara (Persero), Tbk Medan Sharia Branch Impact on Employee Performance}

The leadership of PT Bank Tabungan Negara (Persero), Tbk Medan Syariah Branch has basically indirectly implemented this leadership style. It is very clear that the leadership at PT Bank Tabungan Negara (Persero), Tbk Syariah Medan Branch recognizes the ability of its employees to complete every job well. Not only acknowledging the abilities of their subordinates, company leaders also wisely maximize the abilities of their employees as well as possible through placing positions and assigning job responsibilities to their subordinates in accordance with their abilities and achievements.

This democratic leadership is also seen in the willingness of the leadership to cooperate with subordinates as much as possible including. The manifestation of this attitude is the willingness of the leadership together with their subordinates to review and survey customers directly to customer locations, especially customers who have a large financial value. This is very good because the leadership's willingness to go down directly together with subordinates will provide a high sense of support in employees, and of course it will be valuable for subordinates to provide the best performance.It needs to be said that this democratic leadership style is one of the variables that has a low influence. It is known statistically that the magnitude of the influence of democratic leadership style on performance is 0.216 which is a low influence compared to other variables.

\section{Situational Leadership Style at PT. Bank Tabungan Negara (Persero), Tbk Medan Sharia Branch Impact on Employee Performance}

This situational leadership style is basically applied at least by the leader. Among them is it is known that the leader pays attention in the form of supervision to subordinates at work, at least what is done is by asking for work reports that must be done by subordinates every day before returning from the office, whether according to the direction of the leadership or not, whether it is done or not and so on. This action is very logical, because this action will provide encouragement as well as pressure for subordinates to work in accordance with the directions given.

In addition, the company's leadership makes a policy to provide mutual commitment between the leadership and their subordinates to work well, and to help each other according to the capacity of their main duties and functions. It is important for the company's management to see the work commitment of employees in achieving the company's targets that have been set, besides that, a sense of belonging and responsibility will arise in subordinates to work as much as possible. It should be stated that this situational leadership style is one of the variables that have the lowest influence. It is known statistically that the magnitude of the influence of situational leadership style on performance is 0.185 which is the lowest influence compared to other variables.

\section{CONCLUSION}

1. The transformational leadership style has a significant effect on employee performance. 
2. The democratic leadership style has a significant effect on employee performance.

3. The situational leadership style has a significant effect on employee performance.

4. The transformational leadership style, democratic leadership style and situational leadership style simultaneously have a significant effect on performance.

\section{Acknowledgement: None}

\section{Conflict of Interest: None}

\section{Source of Funding: None}

\section{REFERENCES}

1. Afifah, N. (2017). Gaya Kepemimpinan Transformasional, Orientasi Pasar Dan Kualitas Pelayanan Terhadap Kinerja Pdam Tirta Khatulistiwa Pontianak Kalimantan Barat. EKUITAS (Jurnal Ekonomi Dan Keuangan), $1(1), \quad 1$. https://doi.org/10.24034/j25485024.y2017.v 1.i1.2053

2. Anshar, S. (2019). Penerapan Gaya Kepemimpinan Demokratik Terhadap Peningkatan Kinerja Aparatur Pada Dinas Perhubungan,Komunikasi Dan Informatika Kabupaten Kepulauan Mentawai. https://doi.org/10.31227/osf.io/9vgyj

3. Ardiana, T. E. (2016). Pengaruh Persepsi Guru Atas Gaya Kepemimpinan Situasional Kepala Sekolah Terhadap Kinerja Guru Akuntansi Smk Di Kota Madiun. Jurnal Akuntansi Dan Pajak, 17(01), 1-10. https://doi.org/10.29040/jap.v17i01.57

4. Asmara, I. K. J., \& Widanaputra, A. A. G. P. (2017). Pengaruh Gaya Kepemimpinan Transformasional Dan Budaya Organisasi Pada Kinerja Organisasi Dengan Motivasi Kerja Sebagai Pemoderasi. E-Jurnal Akuntansi, 18, 1575-1603.

5. Baharuddin, \& Umiarso. (2012). Kepemimpinan Pendidikan Islam. Ar-Ruzz Media.

6. Fitria Nur Azizah, Armanu Thoyib, D. D. W. I. (2017). Pengaruh Kepemimpinan Situasional dan Budaya Organisasi Terhadap Motivasi Kerja dan Kinerja Karyawan (Studi Pada Koperasi Agro Niaga
(KAN) Jabung Malang). Jurnal Bisnis Dan Manajemen, 4(1), 1-11.

7. Herlisa., Mariskha, S. E., Umaroh, S. K., \& Yoga, A. R. (2020). Pengaruh Gaya Kepemimpinan Demokratik Terhadap Kinerja. 000, 63-73.

8. Hersey, P., \& Blanchard, K. H. (2003). Manajemen Perilaku Organisasi (H. Pasolong (ed.)). Erlangga.

9. Kesuma, B., \& Syamsuddin, H. (2019). Pengaruh Gaya Kepemimpinandemokratis Dan Motivasi Terhadap Kinerja Karyawan Pt.Panin Bank Cabang Atmo Palembang. Jurnal Ecoment Global, 4(2), 103. https://doi.org/10.35908/jeg.v4i2.758

10. Khosiah, S., \& Maryani, K. (2020). Pengaruh Gaya Kepemimpinan Demokratis Kepala Sekolah Terhadap Kinerja Guru PAUD. Jurnal Golden Age. http://www.ejournal.hamzanwadi.ac.id/index.php/jga/arti cle/view/1874

11. Nurhuda, A., Sardjono, S., \& Purnamasari, W. (2019). Pengaruh Gaya Kepemimpinan Transformasional, Disiplin Kerja, Lingkungan Kerja Terhadap Motivasi dan Kinerja Karyawan Rumah Sakit Anwar Medikal Jl. Raya Bypass Krian KM. 33 Balongbendo - Sidoarjo. 1(1).

12. Priyagung, G. P., \& Wening, N. (2020). Pengaruh Kepemimpinan Demokratis Terhadap Kinerja Karyawan Dengan Motivasi Kerja Sebagai Variabel Intervening (Studi Pada Pegawai Dewan Perwakilan Rakyat Daerah Kota Y). 4(1), 46-54.

13. Purwanto, A., Primahendra, R., \& ... (2020). Pengaruh Gaya Kepemimpinan Tansformational, Authentic, Authoritarian, Transactional Terhadap Kinerja Guru Madrasah Aliyah di Tangerang. Journal .... http://e-journal.staimaalhikam.ac.id/evaluasi/article/view/342

14. Putranto, A., \& Wijayanti, R. (2018). Pengaruh Gaya Kepemimpinan Transformasional, Kompensasi dan Komunikasi Organisasi Terhadap Kinerja Karyawan. Journal of Economic, Management

https://ojs.unsiq.ac.id/index.php/jematech/ar ticle/view/208

15. Robbins, S. P., \& Judge, T. A. (2015). Perilaku Organisasi. In Perilaku Organisasi (Enambelas, p. 229). Salemba Empat.

16. Syah, M. A. (2017). Pengaruh gaya kepemimpinan situasional dan komunikasi 
Novriadi M et.al. Analysis of the impact of leadership determination on employee performance at PT BTN (Persero), Tbk Medan Sharia Branch Office

organisasi terhadap kinerja karyawan. Universitas Muhammadiyah Surakarta, 123.

17. Wiji Astutik. (2017). Pengaruh Pelatihan dan Gaya Kepemimpinan Demokratis Terhadap Kinerja Karyawan PT Cahaya Harta Makmur. Sekolah Tinggi Ilmu Ekonomi Pelita Bangsa.

18. Wote Verawati, A. Y., \& Patalatu, J. S. (2019). Pengaruh Gaya Kepemimpinan Transformasional dan Kepuasan Kerja terhadap Kinerja Guru Sekolah Dasar.
Jurnal Ilmiah Sekolah Dasar, 3(4), 465. https://doi.org/10.23887/jisd.v3i4.21782

How to cite this article: Novriadi M, Nasution $\mathrm{H}$, Absah Y. Analysis of the impact of leadership determination on employee performance at PT BTN (Persero), Tbk Medan Sharia Branch Office. International Journal of Research and Review. 2021; 8(10): 126-132. DOI: https://doi.org/10.52403/ijrr.20211017 